\title{
UJI KANDUNGAN HIDROKSIMETILFURFURAL (HMF) SEBAGAI PARAMETER KUALITAS MADU
}

\author{
Audi Rizki Koesprimadisari ${ }^{1)}$, Dian Arrisujaya ${ }^{2)^{*}}$, Resty Syafdaningsih ${ }^{1)}$ \\ ${ }^{1)}$ Balai Besar Industri Argo \\ Jl. IR. H. Juanda No.11, Paledang, Bogor Tengah, Kota Bogor 16122 \\ ${ }^{2)}$ Program Studi Kimia FMIPA Universitas Nusa Bangsa Bogor \\ Jl. K.H. Soleh Iskandar Km. 4 Tanah Sareal Bogor 16166 \\ e-mail: d1anarrisujaya@gmail.com
}

\begin{abstract}
Hydroxymethylfurfural Content Test as Parameter Quality of Honey

Determination hydroxymethylfurfural $(H M F)$ levels in honey had been done refer to method in SNI 3545:2013. Average of the HMF levels is $64,72 \mathrm{mg} / \mathrm{kg}$ whereas SNI decided maximal limit was $50 \mathrm{mg} / \mathrm{kg}$ so honey quality is not good enough. To support testing result, calculation of reapeatabily with relative standard deviation (RSD) Horwitz and accuracy with \% recovery was done. The result of reapeatabilty showed that analyst reapeatability was good because the relative standard deviation less than 2/3 RSD Horwitz. The result of accuracy was good because both treatment gave recovery $89,28 \%$ and 106,43\%, which in the range of acceptance recovery test for analite concentration about $50 \mathrm{mg} / \mathrm{kg}$.
\end{abstract}

Keywords : HMF, Hydroxymethylfurfural, Honey, Quality of Honey, Reapeatability, Accuracy

\begin{abstract}
ABSTRAK
Penentuan kadar hidroksimetilfurfural (HMF) pada madu telah dilakukan dengan metode yang mengacu pada SNI 3545:2013. Rata-rata hasil kandungan hidroksimetilfurfural adalah 64,72 mg/kg sedangkan batas maksimal yang ditetapkan SNI adalah $50 \mathrm{mg} / \mathrm{kg}$ sehingga kualitas contoh madu tersebut kurang baik. Untuk menunjang hasil pengujian, maka dilakukan perhitungan repeatabilitas dengan menggunakan Standar Baku Relatif (SBR) Horwitz dan perhitungan akurasi menggunakan $\%$ perolehan kembali. Hasil perhitungan repeatabilitas menunjukkan bahwa repeatabilitas analisis HMF baik karena nilai simpangan baku lebih kecil dari 2/3 SBR Horwitz. Perhitungan akurasi pun menunjukan hasil yang baik karena kedua perlakuan memberi hasil perolehan kembali sebesar 89,28\% dan $106,43 \%$, yang masuk kedalam batas keberterimaan uji perolehan kembali untuk konsentrasi analit dalam contoh sekitar $50 \mathrm{mg} / \mathrm{kg}$.
\end{abstract}

Kata Kunci : HMF, Hidroksimetilfurfural, Madu, Kualitas Madu, Reapitabilitas, Akurasi

\section{PENDAHULUAN}

Seiring maraknya peredaran madu palsu, masyarakat seharusnya memiliki pengetahuan yang cukup terkait keaslian madu. Secara kasat mata, menentukan keaslian madu memang sulit dilakukan. Namun, madu asli memiliki kandungan bahan kimia yang berbeda dengan madu palsu. Dari kandungan-kandungan alami madu dan uji laboratorium mengenai keberadaan zat-zat di dalam madu, kita dapat mengetahui keaslian madu. Terdapat beberapa indikasi dalam uji kuantitas yang diperkirakan menandakan bahwa suatu madu adalah madu palsu atau campuran.
Diantaranya yaitu apabila kadar sukrosa madu naik, kadar enzim fluktuatif, kadar abu fluktuatif, kandungan mineral turun, perbedaan aroma dan rasa, dan kandungan hidroksimetilfurfural (HMF) berubah.

HMF pada dasarnya adalah pecahan dari sukrosa dan fruktosa. Kandungan HMF maksimal pada madu adalah $50 \mathrm{mg} / \mathrm{kg}$. Jika lebih dari angka tersebut, dapat dipastikan bahwa madu tersebut palsu atau dicampur karena adanya gula tambahan dari bahan yang dicampurkan. Dari segi perban-dingan, glukosa pada madu asli cenderung lebih banyak dibandingkan gula yang lain. Sedangkan pada madu palsu, kandungan sukrosa cenderung lebih menonjol. Selain 
itu, dengan pengujian kimia sederhana menggunakan $\mathrm{pH}$ meter kita dapat mengetahui keaslian madu. Madu yang diuji terbukti asli apabila memiliki $\mathrm{pH}$ antara 3,4 sampai 4,5. Madu yang memiliki campuran atau secara keseluruhan palsu, biasanya memiliki $\mathrm{pH}$ di atas atau di bawah kisaran tersebut yaitu pada angka 2,4 - 3,3 atau di atas angka 5.

Kadar HMF dapat menjadi indikator kerusakan madu oleh pemanasan yang berlebihan atau karena penambahan gula invert (sebuah campuran bagian yang sama dari glukosa dan fruktosa yang dihasilkan dari hidrolisis sukrosa). Kedua perlakuan tersebut akan meningkatkan kadar HMF (Winarno, 1982). Semakin lama penyimpanan menyebabkan kadar HMF pada madu semakin tinggi (White, 1994).

Kenaikan kadar HMF juga disebabkan oleh suhu penyimpanan. Hal tersebut didukung oleh hasil penelitian Almayanthy (1998) yang menunjukkan bahwa kadar HMF madu yang disimpan pada suhu $28^{\circ} \mathrm{C}$ lebih tinggi dibandingkan pada suhu $3^{\circ} \mathrm{C}$ dan $5^{\circ} \mathrm{C}$. Warna madu akan semakin gelap seiring meningkatnya kadar HMF karena oksigen dari udara akan mengoksidasi HMF sehingga membentuk warna gelap pada madu (Bogdanov et al., 2004).

Tingginya kadar HMF dalam madu akan menurunkan kualitas madu karena kandungan HMF dalam memiliki keterkaitan dengan beberapa karakteristik kimia madu lainnya seperti kadar air, pH, kadar asam bebas, kadar gula pereduksi, serta aktivitas enzimatik dalam madu (Kowalski et al., 2013). Kadar maksimum HMF dalam madu yang ditetapkan oleh Codex Alimentarius dan European Union adalah maksimum $40 \mathrm{mg} / \mathrm{kg}$ untuk madu yang berasal dari daerah beriklim subtropis dan maksimum $80 \mathrm{mg} / \mathrm{kg}$ untuk madu yang berasal dari dearah beriklim tropis (Bogdanov, 2011).

SNI menetapkan kadar HMF dalam madu yakni tidak melebihi $50 \mathrm{mg} / \mathrm{kg}$ (SNI 3545:2013). Selain itu pada beberapa penelitian menyebutkan bahwa HMF memiliki sifat toksisitas, mutagenik dan karsinogenik (Chi et al., 1998; Jankowski et al., 2002).
Madu asli juga memiliki aktivitas enzim diastase yang tinggi. Enzim merupakan senyawa kompleks yang tidak dapat dibuat oleh manusia. Enzim diastaste itu sendiri merupakan enzim yang berfungsi untuk mengubah karbohidrat kompleks atau polisakarida menjadi karbohidrat sederhana atau monosakarida. Enzim ini secara alami berada di dalam madu dan sulit didapatkan dari bahan lainnya. Apabila madu yang diuji memiliki aktivitas enzim diastase minimal 3, maka madu tersebut adalah madu asli. Sedangkan pada madu palsu, aktivitas enzim ini hanya berkisar pada angka yang sangat rendah yaitu 0,005 hingga 0,1 . Selain itu terdapat pula enzim lain di dalam madu yaitu invertase yang berfungsi untuk memecah molekul sukrosa menjadi glukosa dan fruktosa, glukosa oksidase yang berperan sebagai pembantu oksidasi glukosa menjadi asam peroksida, peroksidase yang melakukan proses oksidasi metabolisme, serta lipase.

Madu mengandung banyak mineral seperti natrium, kalsium, magnesium, alumunium, besi, fosfor, dan kalium. Vitamin-vitamin yang terdapat dalam madu adalah tiamin (B1), riboflavin (B2), asam askorbat (C), piridoksin (B6), niasin, asam pantotenat, biotin, asam folat, dan vitamin $\mathrm{K}$ (Suranto, 2004).

Perbedaan nyata antara madu murni dan madu tidak murni terletak pada komposisi kimianya (Sutami, 2003). Terdapat beberapa cara untuk mengetahui kemurnian madu, salah satunya dapat dilakukan uji gula dengan cara Kromato-grafi Cair Kinerja Tinggi (KCKT) atau High Peformance Liquid Cromatografi (HPLC) (Ratnayani et al., 2008).

Analisis kimia yang membutuhkan tenaga ahli dan peralatan khusus, tidak semua orang dapat melakukannya, maka pengujian madu pada prakteknya di lapangan sering diuji dengan cara-cara berdasarkan pengetahuan atas informasi yang berhubungan di masyarakat walaupun belum dapat dibuktikan keakuratannya. Beberapa cara yang sering digunakan masyarakat untuk menilai kemurnian madu antara lain menguji kemurnian madu seperti menggunakan semut, perembesan madu bila ditetes ke koran, korek api yang dicelupkan 
dalam madu murni masih dapat menyala, berwarna kuning tua, madu akan mengkristal jika diaduk ke dalam kuning telur, menyimpan gas atau udara, tidak membeku bila dimasukan ke dalam lemari es. Berdasarkan informasi tersebut berkembanglah beberapa cara pengujian kemurnian madu. Pengujian tersebut belum teruji keefektifannya.

Ansori (2002) melakukan pengujian kemurnian madu yang ditambahkan dengan sukrosa, fruktosa, glukosa dan gula aren dengan menggunakan uji bakar, uji rembes, uji koagulasi, uji kristalisasi, dan uji larut, dan dari kelima uji tersebut hanya uji larut yang paling akurat untuk menguji kemurnian madu. Selain kelima uji tersebut masih banyak uji lainnya yakni uji kelarutan, uji pemanasan, uji tarik, uji lengket, uji ikan mentah, uji buih, dan uji iod yang telah diketahui akurasinya menggunakan beberapa sampel madu palsu.

Madu memiliki banyak manfaat sehingga marak terjadi pemalsuan madu. Masyarakat perlu mengetahui kualitas madu yang dikonsumsinya. Salah satunya dengan melakukan pengujian kandungan hidroksimetilfurfural (HMF) dalam madu.

Dari segi ilmu kimia, terdapat beberapa analisa yang bisa dilakukan untuk mengetahui keaslian madu. Analisis karbon, analisis mikroskopis, analisis HMF, analisis polaritas cahaya merupakan beberapa uji yang biasa dilakukan untuk mengetahui keaslian madu. Uji kimia yang dilakukan adalah analisis hidroksi-metilfurfural (HMF). Pengukuran kadar HMF pada madu menggunakan spektro-fotometer, dan pengolahan data hasil analisis hidroksimetilfurfural meliputi Standar Baku Relatif (SBR) Horwitz dan \% perolehan kembali atau recovery.

\section{BAHAN DAN METODE}

\section{Bahan dan Alat}

Bahan yang digunakan yaitu madu, akuades, larutan Carrez I, larutan Carrez II, natrium bisulfit $0,2 \%$, dan kertas saring.

Peralatan yang digunakan yaitu neraca analitik, alat-alat kaca dan spektrofotometer UV/Vis HP 8453.

\section{Metode}

1. Analisis Hidroksi Metilfurufal

a. Pembuatan Larutan Blanko

Akuades ditambahkan larutan Carrez I dan Carez II masing-masing 0,50 $\mathrm{mL}$ hingga batas volume $50 \mathrm{~mL}$.

\section{b. Preparasi Sampel}

Preparasi sampel dilakukan untuk menjernihkan larutan dengan pengendapan protein yang akan dianalisa menggunakan spektro-fotometer UV. Sampel madu sebanyak 5 gram dilarutkan dengan akuades hingga volume $25 \mathrm{~mL}$. Larutan sampel ditambahkan larutan Carrez I dan Carrez II masing-masing sebanyak $0,50 \mathrm{~mL}$. Kemudian larutan ditambahkan akuades dan dihomogenkan hingga volume $50 \mathrm{~mL}$. Larutan sampel disaring hingga jernih. Larutan sampel sebanyak $1 \mathrm{~mL}$ ditambahkan akuades sebanyak $19 \mathrm{~mL}$ merupakan larutan A.

Larutan pembanding dibuat dari natrium bisulfit $0,2 \% \quad 10 \mathrm{~mL}$ dan natrium bisulfit $0,1 \% 9 \mathrm{~mL}$ dan dihomogenkan. Larutan pembanding ini merupakan larutan B.

c. Pengujian Sampel

Larutan A dan larutan B dibaca menggunakan spektrofotometer pada panjang gelombang $284 \mathrm{~nm}$ dan $336 \mathrm{~nm}$.

\section{Perhitungan}

Perhitungan konsentrasi hidroksimetilfurfural (HMF) dapat dilakukan dengan menggunakan rumus yang terdapat pada SNI 3545:2013.

$$
\begin{aligned}
& \operatorname{HMF}\left(\frac{\mathrm{mg}}{100} \mathrm{~g} \text { madu }\right)=\frac{\mathrm{A}_{284}-\mathrm{A}_{336} \times 14,97 \times 5}{\text { bobot sampel }(\mathrm{g})} \\
& \text { Faktor }=\frac{126}{16830} \times \frac{1000}{10} \times \frac{100}{5}=14,97
\end{aligned}
$$

Keterangan:

126 : bobot molekul HMF

16830 : absortivitas molar HMF pada panjang gelombang $284 \mathrm{~nm}$

$1000: \mathrm{mg} / \mathrm{g}$

$10: \mathrm{cL} / \mathrm{L}$

100 : gram madu yang dilaporkan

5 : bobot sampel dalam gram 


\section{HASIL DAN PEMBAHASAN}

Analisis hidroksimetilfurfural (HMF) pada madu dilakukan dengan menggunakan metode spektrofotometri. Analisis HMF dilakukan untuk mengetahui kualitas madu yang dipengaruhi oleh pemanasan yang berlebihan, penambahan gula invert dan suhu penyimpanan madu. Kualitas madu tidak dapat ditentukan hanya dengan analisis HMF, tetapi perlu dilakukan analisis lainnya seperti aktivitas enzim diastase, kadar air, gula pereduksi, sukrosa.

Analisis HMF dapat memberikan informasi yang diperlukan untuk memperkirakan total paparan panas dari setiap jenis madu. Termasuk panas yang digunakan dalam pengolahan, penyimpanan atau pengiriman. Madu yang baru dipanen pun sudah mengandung HMF dan tidak bergantung pada jenis madunya.

Analisis HMF ini menggunakan beberapa pereaksi yang memiliki fungsi tersendiri. Larutan Carrez I dan Carrez II berfungsi untuk mengendapkan protein. Larutan natrium bisulfit digunakan sebagai pembanding. Hasil pengukuran konsentrasi HMF dapat dilihat pada Tabel 1.

Dari tabel dapat dilihat konsentrasi ratarata HMF yang didapat pada sampel madu lebih besar yaitu $64,72 \mathrm{mg} / \mathrm{kg}$ dari batas maksimal yang ditetapkan SNI adalah 50 $\mathrm{mg} / \mathrm{kg}$ sehingga kualitas sampel madu tersebut kurang baik. Perhitungan konsentrasi hidroksimetilfurfural terdapat pada Lampiran 2.

Tingginya nilai HMF $(64,72 \mathrm{mg} / \mathrm{kg})$ bisa disebabkan oleh kerusakan yang terjadi dari proses pemanasan madu setelah dipanen maupun proses penyimpanan yang kurang baik (terkena sinar matahari langsung). Penelitian yang dilakukan oleh Soleha (2015) membandingkan pengaruh suhu pemananasan dan lama penyimpanan terhadap kualitas madu asal Desa Terasa. Hasil penelitian tersebut dapat dilihat pada Tabel 2.

Tabel 1. Konsentrasi HMF pada Madu Dibandingkan dengan SNI 3545:2013

\begin{tabular}{cc}
\hline Ulangan & Hasil Analisis $(\mathrm{mg} / \mathrm{kg})$ \\
\hline 1 & 60.63 \\
2 & 59.71 \\
3 & 65.46 \\
4 & 65.95 \\
5 & 66.21 \\
6 & 66.65 \\
7 & 68.44 \\
\hline Rata-rata & 64.72 \\
SNI 3545:2013 & 50.00 \\
\hline
\end{tabular}

Tabel 2. Kadar HMF Madu Asal Desa Terasa Berdasarkan Lama Penyimpanan dan Waktu Pemanasan

\begin{tabular}{ccc}
\hline Sampel & Perlakuan & Kadar HMF $(\mathrm{mg} / \mathrm{kg})$ \\
\hline S1 & Penyimpanan 1 bulan & 32,2063 \\
S2 & Penyimpanan 2 bulan & 55,6775 \\
S3 & Penyimpanan 3 bulan & 61,7024 \\
S4 & Penyimpanan 4 bulan & 88,7168 \\
S35 & Pemanasan $35^{\circ} \mathrm{C}$ & 54,8764 \\
S90 & Pemanasan $90^{\circ} \mathrm{C}$ & 68,5644 \\
S110 & Pemanasan $110^{\circ} \mathrm{C}$ & 182,3035 \\
\hline
\end{tabular}

Sumber : Soleha, 2015 
Tabel 3. Repeatabilitas Hasil Analisis Hidroksimetilfurfural (HMF)

\begin{tabular}{|c|c|}
\hline Ulangan & Hasil Analisis (mg/kg) \\
\hline 1 & 60.63 \\
\hline 2 & 59.71 \\
\hline 3 & 65.46 \\
\hline 4 & 65.95 \\
\hline 5 & 66.21 \\
\hline 6 & 66.65 \\
\hline 7 & 68.44 \\
\hline Jumlah & $: 517.77$ \\
\hline Rata-rata & $: 64.72$ \\
\hline SB & $: 3.0141$ \\
\hline SBR perhitungan & : SB/rata-rata x $100 \%$ \\
\hline SBR perhitungan & $: 4.66$ \\
\hline SBR Horwitz & $2^{(1-0.5 \log C)}$ \\
\hline SBR Horwitz & $: 8.5414$ \\
\hline 2/3 SBR Horwitz & : 5.6943 \\
\hline
\end{tabular}

Untuk menunjang hasil pengujian, maka dilakukan pula perhitungan repeatabilitas dilakukan menggunakan Standar Baku Relatif (SBR) Horwitz dengan rumus $2^{(1-0.5 \log \mathrm{C})}$. Tujuan dari pengulangan adalah untuk mengetahui presisi data yang diperoleh oleh analis. Pengulangan dilakukan sebanyak tujuh kali karena percobaan keseksamaan dilakukan terhadap minimal enam replika sampel yang diambil dari campuran sampel dengan matriks yang homogen. Perhitungan repeatabilitas hasil analisis hidroksimetilfurfural terdapat pada Tabel 3. Dari hasil yang didapatkan dapat disimpulkan bahwa repeatabilitas analisis HMF baik karena nilai simpangan baku lebih kecil dari 2/3 SBR Horwitz.

Perhitungan akurasi didapatkan dari $\%$ perolehan kembali atau recovery. Perolehan kembali atau recovery dilakukan dengan metode adisi (penambahan standar). Dapat dilihat dalam persamaan berikut :

$\%$ Perolehan kembali (recovery)

$$
=\frac{\mathrm{C} 1-\mathrm{C} 2}{\mathrm{C} 3} \times 100 \%
$$

Sampel yang akan dianalisis ditambahkan sejumlah standar yang telah diketahui konsentrasinya lalu dilakukan analisis bersama dengan sampel lainnya. Selisih kedua hasil dibandingkan dengan konsentrasi yang sebenarnya. Dengan C1 adalah konsentrasi dari analit dalam campuran sampel + sejumlah tertentu analit, C2 adalah konsentrasi dari analit dalam sampel, dan C3 adalah konsentrasi dari analit yang ditambahkan kedalam sampel. Hasil perhitungan perolehan kembali dapat dilihat pada Tabel 4.

Tabel 4. Persen Perolehan Kembali (\% recovery)

\begin{tabular}{cccccccc}
\hline No & $\begin{array}{c}\text { Sampel } \\
\text { (gram) }\end{array}$ & $\begin{array}{c}\text { Konsentrasi } \\
\text { sampel }+ \\
\text { standar } \\
(\mathrm{mg} / \mathrm{kg})\end{array}$ & $\begin{array}{c}\text { Jumlah } \\
\text { standar }\end{array}$ & $\begin{array}{c}\text { Konsentrasi } \\
\text { standar yang } \\
\text { ditambahkan }\end{array}$ & $\begin{array}{c}\text { Rata-rata } \\
\text { konsentrasi } \\
\text { sampel } \\
(\mathrm{mg} / \mathrm{kg})\end{array}$ & $\begin{array}{c}\text { Konsentrasi } \\
\text { standar yang } \\
\text { ditambahkan } \\
\text { dalam sampel } \\
(\mathrm{mg} / \mathrm{kg})\end{array}$ & $\begin{array}{c}\% \\
\text { Recovery }\end{array}$ \\
\hline 1 & 5.1381 & 116.85 & $0.2 \mathrm{~mL}$ & $1500 \mathrm{ppm}$ & 64.72 & 58.39 & 89.28 \\
2 & 5.9582 & 118.31 & & & & 50.35 & 106.43 \\
\hline
\end{tabular}


Batas keberterimaan uji perolehan kembali untuk konsentrasi analit dalam sampel sekitar $50 \mathrm{mg} / \mathrm{kg}$ adalah $80-110 \%$. Uji perolehan kembali yang dilakukan dari dua kali perlakuan didapatkan hasil yang memenuhi syarat keberterimaan. Pengujian pertama memberi hasil perolehan kembali sebesar $89,28 \%$ dan pengujian kedua memberi hasil perolehan kembali sebesar $106,43 \%$.

Perbedaan hasil yang diperoleh dari kedua pengujian tersebut dapat disebabkan oleh beberapa faktor saat persiapan sampel, diantaranya:

a. Neraca yang tidak dalam kondisi baik dan bersih saat penimbangan. Untuk menghindarinya dapat dilakukan pembersihan bagian pinggan neraca, penempatan posisi gelembung udara dibagian tengah lingkaran dan peneraan neraca sebelum digunakan.

b. Bahan kimia yang terkontaminasi. Untuk menghindarinya dapat dilakukan dengan memberi label pada setiap bahan kimia yang digunakan, mengambil bahan kimia dengan peralatan yang bersih dan menutup kembali bahan kimia setelah digunakan.

c. Kesalahan saat pemipetan standar. Untuk menghindarinya dapat dilakukan dengan bekerja secara teliti.

d. Larutan yang kurang homogen. Untuk menghindarinya dapat dilakukan dengan melakukan penghomogenan larutan sampel dengan baik.

e. Kesalahan saat proses pengenceran. Untuk menghindarinya dapat dilakukan dengan bekerja secara teliti dan menggunakan gelas ukur dengan rentang skala yang lebih kecil.

f. Peralatan yang kurang bersih. Untuk menghindarinya dapat dilakukan dengan membilas kembali peralatan yang akan digunakan menggunakan air suling atau larutan yang akan digunakan, dan bila diperlukan peralatan yang kering maka setelah pembilasan dapat dilakukan pengeringan dalam oven.

Selain kesalahan saat persiapan sampel, terdapat pula kesalahan yang dapat disebabkan oleh spektrofotometer. Kesalahan yang mungkin terjadi dalam analisis ini adalah kesalahan fotometri yang disebabkan oleh larutan yang terlalu pekat. Dalam SNI 3545:2013 disebutkan bahwa “ Bila absorban lebih tinggi dari 0,6 untuk memperoleh hasil yang teliti, larutan sampel diencerkan dengan air sesuai kebutuhan. Demikian juga dengan larutan pembanding (larutan referensi) encerkan dengan cara sama dengan menggunakan larutan $\mathrm{NaHSO}_{3} 0,1 \%$ nilai absorban yang diperoleh dikalikan dengan faktor pengenceran sebelum perhitungan".

Prosedur kerja yang digunakan pun sedikit berbeda dengan yang tercantum pada SNI 3545:2013. Perbedaan ini terjadi saat proses pemipetan sampel dan pengencerannya. Dalam SNI 3545:2013 jumlah sampel yang dipipet adalah $5 \mathrm{~mL}$, namun pada pengerjaannya jumlah sampel yang dipipet hanya $1 \mathrm{~mL}$. Hal ini dilakukan karena absorban yang didapatkan akan lebih dari 0,6 bila sampel dipipet sebanyak $5 \mathrm{~mL}$. Perbedaan pada proses pengenceran pun terjadi karena dalam SNI 3545:2013 jumlah akhir larutan yang akan dibaca pada spektrofotometer adalah $10 \mathrm{~mL}$, jumlah tersebut dikhawatirkan tidak mencukupi jika digunakan untuk membilas kuvet spektrofotometer.

Pembacaan pada spektrofotometer dilakukan pada panjang gelombang $284 \mathrm{~nm}$ dan $336 \mathrm{~nm}$, kedua panjang gelombang tersebut berada pada daerah radiasi UV. Untuk dapat dibaca pada daerah radiasi UV, sampel harus mengandung kromofor. Pada HMF, yang menjadi kromofor adalah gugus $\mathrm{C}=\mathrm{C}$ dan $\mathrm{C}=\mathrm{O}$, sedangkan gugus hidroksi ($\mathrm{OH})$ berperan sebagai auksokrom.

\section{KESIMPULAN}

Dari hasil analisis hidroksimetilfurfural (HMF) pada madu menunjukkan nilai hidroksimetilfurfural melebihi batas persyaratan yang ditetapkan oleh SNI 3545:2013. Hal tersebut menunjukan telah terjadi kerusakan pada sampel madu yang dianalisis sehingga madu tersebut memiliki kualitas yang kurang baik. Kerusakan tersebut dapat disebabkan oleh proses pemanasan madu setelah dipanen maupun proses 
penyimpanan yang kurang baik (terkena sinar matahari langsung).

Perhitungan repeatabilitas dengan menggunakan Standar Baku Relatif(SBR) Horwitz dan akurasi dengan menggunakan $\%$ perolehan kembali atau recovery menunjukkan nilai yang baik.

\section{DAFTAR PUSTAKA}

Almayanthy, D. 1998. Kualitas madu randu pada suhu penyimpanan yang berbeda. Skripsi. Fakultas Peternakan, IPB. Bogor.

Ansori, F. M. 2002. Studi keakuratan beberapa cara uji keaslian madu. Skripsi. Jurusan Teknologi Hasil Ternak, Fakultas Peternakan, IPB. Bogor.

Badan Standardisasi Nasional. 2013. SNI 3545:2013 Madu.

Bogdanov, S., K. Ruoff, L. P. Oddo. 2004. Physico-Chemical Methods For The Characterisation Of Unifloral Honeys: A Review. Apidologie. 35(2): 4-17.

Bogdanov, S. 2011. Honey as Nutrient and Food Function Food. Bee Product Science.

Chi, W., C. B. Zhang, Y. H. Lao, L. Y. Guo. 1998. Investigation of the Restriction on The Formation of HMF. J.Pharm. 14(1): 101-104.

Kowalski, S., M. Lukasiewicz, A. DudaChodak, G. Ziec. 2013. 5Hydroxymethyl-2-Furfural HeatInduced Formation Occurance in Food and Biotransfromation: a Review. Polish Journal of Food and Nutrition Science. 63 (4): 207225 .

Ratnayani, K., N. M. A. D. Adhi S., I .G. A. M. A. S. Gitadewi. 2008. Penentuan kadar glukosa dan fruktosa pada madu randu dan madu kelengkeng dengan metode kromatografi cair kinerja tinggi. Jurnal Kimia. 2 (2) : 77-86.

Soleha, R. M. 2015. Pengaruh Suhu Pemanasan dan Lama Penyimpanan Terhadap Kualitas Madu Asal Desa Terasa Berdasarkan Kandungan 5-(Hidroksimetil) Furan-2-Karbaldehida (HMF). Skripsi. Jurusan Kimia, Fakultas Matematika dan Ilmu Pengetahuan Alam, Universitas Hasanuddin. Makassar.

Suranto, A. 2004. Khasiat \& Manfaat Madu Herbal. PT Agro Media Pustaka. Depok.

Sutami, A. 2003. Pengaruh waktu penyimpanan dalam refrigerator terhadap komposisi kimia madu asli dan madu palsu. Skripsi. Jurusan Ilmu Produksi Ternak, Fakultas Peternakan, IPB. Bogor.

White, J. W. 1994. The role of HMF and diastase assays in honey quality evaluation. Bee World. 75(3): 104117

Winarno, F. G. 1982. Madu : Teknologi, Khasiat dan Analisa. Ghalia Indonesia. Jakarta. 
Lampiran 1. Hasil Pembacaan Hidroksimetilfurfural (HMF) dengan Spektrofotom

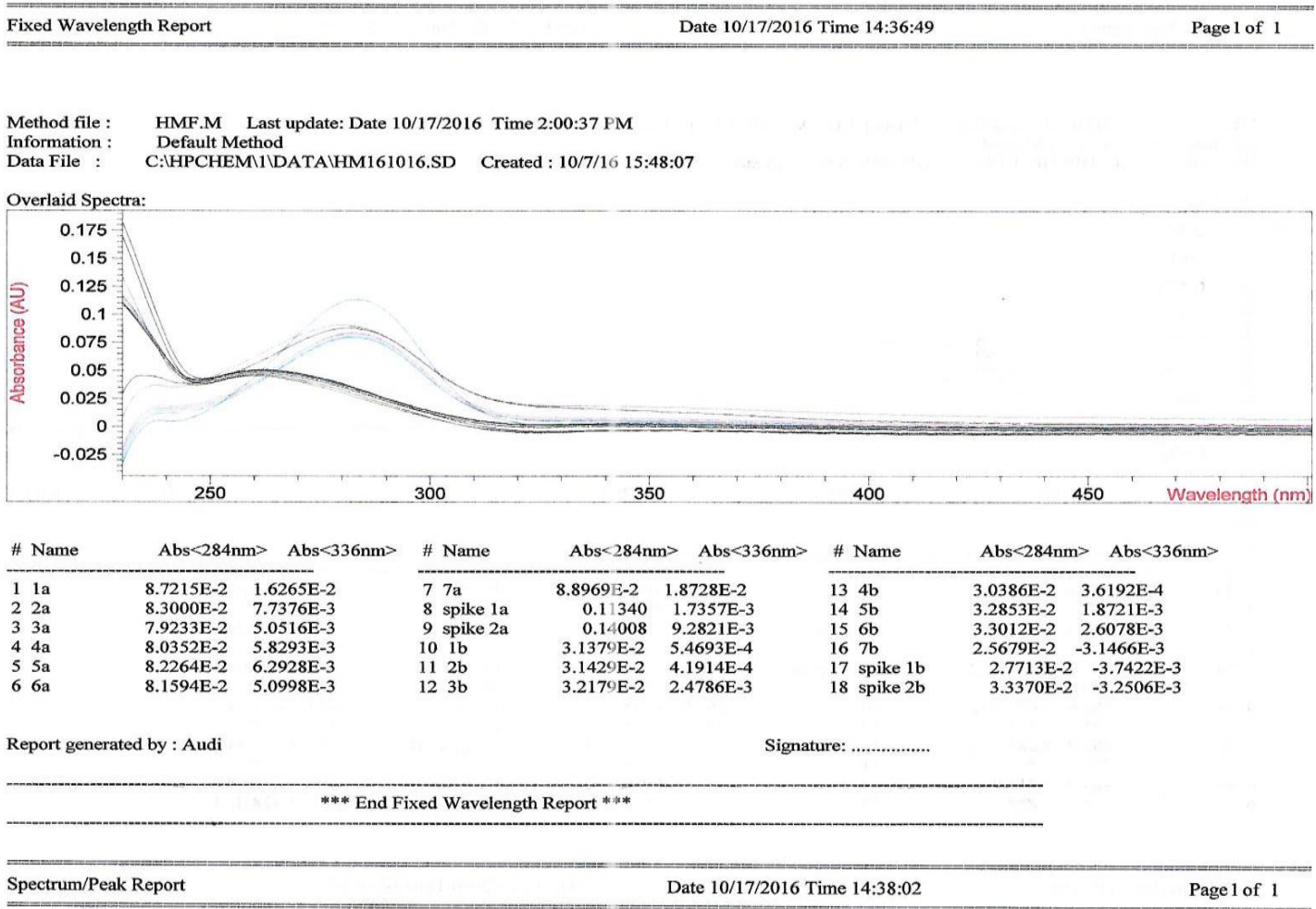

Method file: $\quad$ HMF.M (modified) Last update: Date 10/17/2016 Time 2:37:59 PM

Data File : C:IHPCHEMI1 DATAIHM161016.SD Created : 10/7/16 15:48:07

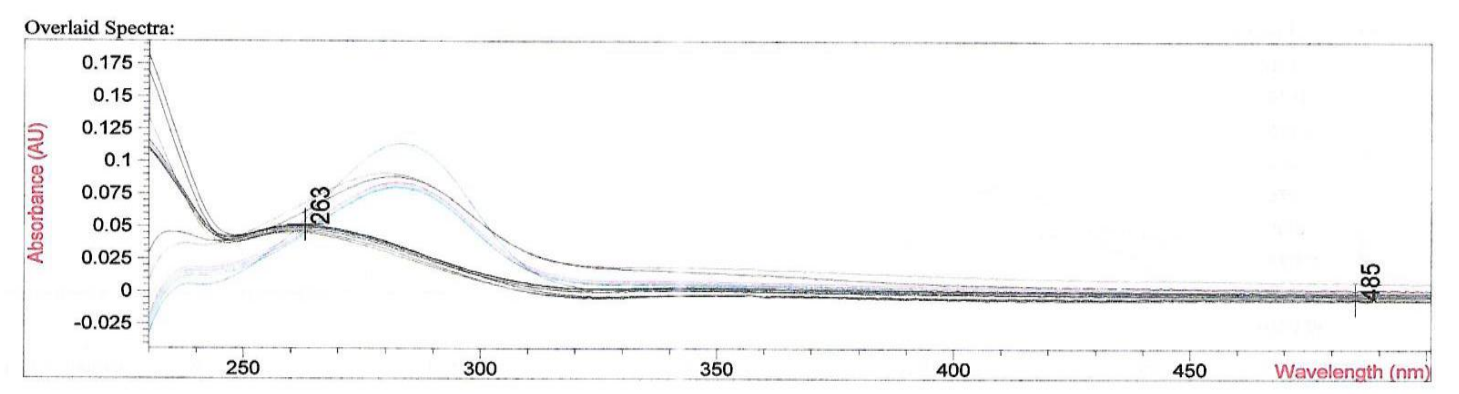

\begin{tabular}{|c|c|c|c|c|c|c|}
\hline \# Name & Peaks & $\operatorname{Abs}(\mathrm{AU})$ & \# Name & Peaks(nm) & \# Name & Peaks(nm) \\
\hline I 1a & 282,0 & $8.8175 \mathrm{E}-2$ & $77 \mathrm{a}$ & $280.0 \quad 9.0607 \mathrm{E}-2$ & $134 b$ & $263.0 \quad 4.7484 \mathrm{E}-2$ \\
\hline 1 & 234.0 & $4.5411 \mathrm{E}-2$ & 7 & $238.0 \quad 3.6862 \mathrm{E}-2$ & 13 & 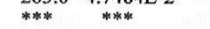 \\
\hline $22 \mathbf{a}$ & 282.0 & $8.3725 \mathrm{E}-2$ & 8 spike $1 \mathrm{a}$ & $283.0 \quad 0.11349$ & $145 \mathrm{~b}$ & $263.0 \quad 5.0375 \mathrm{E}-2$ \\
\hline 2 & 239.0 & $1.8166 \mathrm{E}-2$ & 8 & $238.0 \quad 5.3601 \mathrm{E}-3$ & 14 & $* * * * * * * *$ \\
\hline $33 \mathbf{a}$ & 282.0 & $7.9812 \mathrm{E}-2$ & 9 spike $2 a$ & $284.0 \quad 0.14008$ & $156 \mathrm{~b}$ & $263.0 \quad 5.0404 \mathrm{E}-2$ \\
\hline 3 & $* * * *$ & **** & 9 & $238.0 \quad 2.2541 \mathrm{E}-2$ & 15 & $* * * * * * * *$ \\
\hline $44 a$ & 282.0 & $8.0722 \mathrm{E}-2$ & $10 \mathrm{lb}$ & $263.0 \quad 4.8956 \mathrm{E}-2$ & $167 \mathrm{~b}$ & $261.0 \quad 4.5469 \mathrm{E}-2$ \\
\hline 4 & **** & ${ }^{* * * *}$ & 10 & ***; & 16 & $* * * \quad * * * *$ \\
\hline $55 a$ & 282.0 & $8.2845 \mathrm{E}-2$ & $112 \mathrm{~b}$ & $263.0 \quad 4.3964 \mathrm{E}-2$ & 17 spike $1 \mathrm{~b}$ & $261.0 \quad 4.6341 \mathrm{E}-2$ \\
\hline 5 & $* * * *$ & & 11 & **** & 17 & $* * * * \quad * * *$ \\
\hline $66 a$ & 283.0 & $8.2118 \mathrm{E}-2$ & $123 b$ & $262.0 \quad 4.9707 \mathrm{E}-2$ & 18 spike $2 b$ & $263.0 \quad 5.0987 \mathrm{E}-2$ \\
\hline 6 & & ***** & 12 & $* * * \quad * * *$ & 18 & $485.0-5.4283 \mathrm{E}-3$ \\
\hline \multicolumn{5}{|c|}{ Report generated by : Audi } & \multicolumn{2}{|c|}{ Signature: ...................... } \\
\hline
\end{tabular}

